\title{
Attempts to extend the suffrage in wartime Hungary - 1914-1918
}

\author{
Irén SIMÁNDI
}

\author{
Kodolányi János Főiskola \\ Kodolányi János University, Székesfehérvár \\ Fürdő u. 1, 8000 Székesfehérvár, Hungary \\ simandiiren@upcmail.hu
}

\section{Efforts of the Hungarian social democracy}

The Hungarian Social Democratic Party (founded in 1890) included the protection of women and the extension of political and general equality before the law to women in its programme of 1903. The $5^{\text {th }}$ article of the programme accepted by the $10^{\text {th }}$ Congress of the party (12-14 April 1903) was concerned with the emancipation of women. The demands of the party contained significant statements of intent concerning female suffrage. The most important was the following: "1. Universal, equal, direct suffrage in the case of every election, and the vote for all the citizens of the nation above the age of 20 without any differentiation by sex. Secret ballots in every township. Proportional representation. All voters have the right to be elected." The $8^{\text {th }}$ article of the programme determined educational quota as a primary condition of eligibility to vote. ${ }^{2}$

As the Social Democratic Party gained ground its increasing popularity brought about the establishment of the organizational framework of the social democratic women's rights movement, and this then reinforced its activity, launching a journal called "Nömunkás' (The Woman Worker), founded in March 1905.) One of the functions of this journal was to organize the struggle for suffrage of woman, equality before the law, and to raise the level of education and culture for theirs. ${ }^{3}$

After the outbreak of war the journal described the struggle, everyday problems, means of subsistence and childcare difficulties faced by women living in the most difficult social situations; furthermore, it provided a glimpse into their struggles for the right to vote.

As a consequence of the war all the tasks in a household fell to women, including those that had previously been carried out by men as pointed out in an article published on 15

\footnotetext{
1 This study was published without any omission in 2009 in: Irén SIMÁNDI, Küzdelem a nők parlamenti választójogáért Magyarországon 1848-1938, Budapest 2009.

2 Programme and rules of the Hungarian Social Democratic Party from 1903. Politikatörténeti és Szakszervezeti Levéltár (Archive of History of Politics and Trade Unions in Budapest), 940. fond. 2. ö. e. (guarding unit), 1-2.

3 "Nőmunkás" (The Woman Worker) was published between 1905 and 1949 with several breaks. Its first editor was Mária Gárdos. Éva LAKATOS, Magyar Irodalmi Folyóiratok. A Petőfi Irodalmi Múzeum Bibliográfiai Füzetei, Budapest. 1981, A, sorozat (series) 17-19, 2115. tétel (item).
} 
February 1915 in ,Nömunkás'. Before the war fathers were in a strong position in the family, their word was final for the children - now in a new situation women became the heads of their families. Lots of women had no other choice but to take up work in factories, plants or in service industries so as to provide the daily nourishment for their children and for themselves. The above mentioned article called attention to the aftermath of the war and urged the fixing of maximum prices for food to avoid speculation on the part of merchants. According to the article it was the government's obligation to make sure that food was provided in the hinterland and to take effective measures to prevent food shortages and high prices. The journal called upon social democratic working women to show solidarity with each other and the rest of the society as well, despite their difficulties. The author of the article expressed their hope that the war would be ended as soon and with as little loss as possible. ${ }^{4}$

The issue of ,Nőmunkás' on 15 December 1915 dealt with a parliamentary debate held on 19 December in the chamber of deputies. Sándor Gesswein, a christian socialist politician, and Nándor Juriga, a representative of the national minorities, proposed the extension of suffrage to women. In the course of the discussion count József Károlyi summarized his opinion briefly, as reported in "Nőmunkás': „What an idea! - shouted in the count" in the course of a debate on the possibility of providing the right for women to take part in framing legislation which "they are obliged to obey, and which thus has a decisive influence on their lives too".

"Suffrage for women too!" - continued the author of the article, quoting the observation of Count József Károlyi. „To be sure, if women took part in the framing of laws, they would be able to enact laws which would make impossible bloody wars like this, and then how could landowner counts gain millions? Or, if women happened to be unable to avert war, they could arrange the supply of food in a more expedient and equitable way, and this would mean a real danger for, gentlemen' speculating on the wartime market. [...] God forbid! Suffrage for women! [...] How could this right be due to women?", as Irén Müller went on in her report. „What do they do on behalf of our country, state or society since they are even not able to die a hero's death for the country? "

How "do they dare to claim rights" for women when those men who are doing their military service in the war do not have the right to vote either, although "it would be understandable if they claimed their rights; these times, however, are not suitable for arranging an issue like this", as the author summarized Count Károlyi's thoughts.

In her reply, Irén Müller then went on to enumerate what women wanted and did during the war years. "They give birth to trifling millions of soldiers, meanwhile they suffer pain and face death all the time; or now, when the flower of the men are far from their homes, women form the pillars of the state, without which its structure would collapse; women perform the greater part of agricultural production; women are in the hospitals trying to nurse the wounded back to life; women are working in factories and plants producing war materials to provide the required ammunition, nourishment and clothing for the army; they are everywhere: in industry, commerce, in workshops and in offices, in public administration and on the trams, fighting against the usury which threatens from a thousand sides, and

4 A háztartás háborúban. Nőmunkás, 15 February 1915, 1-2. 
doing the work imposed on them firmly and steadily in order to make sure that society can carry on working without interruption."

We can declare - continued the author of the article - that women in the hinterland "are equal to men in their achievements". While men have only one duty, that is, to hold their ground on the front line, women have to perform their household duties and take care of their children; they have to struggle against the high cost of living every day, and all of these are accompanied by an unending anxiety for their absent relatives. This way of life undermines their health and makes their life - that is not long in any case - even shorter.

"But, so it seems, wrote the author in the article, "the Count has slept through the last one and a half years and he has not noticed the changes that this society has undergone, which have gained for women an absolutely equal position to that of men since the war broke out". Women had proved to be able to work independently and to cope with the most difficult tasks in the midst of the worst conditions, and thanks to this they have gained the right to demand that they take part in controlling their own and their children's lives.

Irén Müller encouraged working women to fight to the utmost after the war for "a universal, equal and secret suffrage without any distinction of sex". ${ }^{5}$

The organized working women of Hungary held their $5^{\text {th }}$ Congress on 13 May 1915. „Nőmunkás' reported in a series of articles on the events of the congress. In the issue published on 1 August the journal reported on Sári Goldschmied's talk about women's suffrage: „Up to now, we, social democratic working women, have been fighting for the political rights of working women, and making efforts in the political education of working women, but considering Hungarian conditions we laid stress upon men's right to vote" said the speaker in a thought-provoking statement.

Women's role has changed during the war, and the „increasing importance" of their work cries out for them being granted an equal right to vote to men. The Social Democratic Party has taken a stand for the political right of women and this fight has not been easy, but the war "has determined a new direction" for this fight. A new movement for women's suffrage has emerged all over the world, setting into action even those women who were previously unconcerned, all of those would join the fight of the social democrats "who do not want to turn a deaf ear to progress, and who are willing to save the world from such disasters as this". If they want to grant the right to vote to men who are doing their military service on the front line, then "why could those women not be granted the same reward, those women who ensured the normal functioning of the economy of the state amid so much indigence and suffering".

In the speaker's opinion, "if as many mothers as fathers had taken a seat in the parliaments of Europe, if women had been given seats around the green tables of diplomacy in equal proportion to men, this war would never have happened. It springs from the (very) nature of women that humanity could have avoided the bloodshed. One piece of evidence for this is the fact that in the first days of the war when ,war fever took a hold of even sober men, when the atmosphere that was artificially called into being in the crowds stirred fathers, women were mothers even those times, and thanks to their often-profaned womanly steadiness they have remained mothers up to this day."

5 „Még mit nem!?”, in: Nőmunkás, 15 December 1915, 1-2. Comments of Nándor Juriga representative: Képviselőházi Napló, 1910-1915. Vol. XXVII, Budapest 1916, 369-370. 
The social democratic movement was the first to raise its voice against the war, and they would be the first to bring into being peace. In order to realize this aim, the watchword of the Congress must be forwarded to every part of the world: "the idea of peace and universal, equal, secret suffrage that is extended to women too" - finished Sári Goldschmied her speech. ${ }^{6}$

In its issue published on 1 November 1917 ,Nömunkás' covered a public conference of social democratic working women held on $21^{\text {st }}$ October and organized by their national committee. The aim of this conference was to discuss a part of the suffrage bill then in preparation concerning women's suffrage on behalf of social democratic working women and men.

The first speaker, Ernőné Müller emphasized that the Social Democratic Party had already seriously demanded the right to vote for women even when nobody else would occupy themselves with the idea of women's emancipation. She believed that those women's selfsacrifice who as a consequence of the war held out in every sector of agricultural work would be evidence in support of their fight for suffrage.

„But the war has changed women's way of thinking radically, since a woman cannot be so narrow-minded as not to realize the fact that she has to be concerned about public affairs and politics because every woman can experience the consequences of the policies of the state in her family, home, and most personal matters". Realizing this, masses of working women are demanding "the right that provides the opportunity for them to take part in public affairs: real suffrage that is extended to women too". The news that it was intended that working women be left out of the extension of rights caused great indignation among them. The speaker said that such a limitation of suffrage would mean a disadvantageous situation not only for working women but "it would greatly lower the value of the effectiveness of suffrage given working men too". "Since those women who would get in on the basis of educational and property qualifications would mostly support the reactionary parties and the politics of the proprietor classes, and actually would be nothing else but extra votes provided for the rich."

The next speaker, Zsigmond Kunfi, a social democratic politician, emphasized among other things that women had gained the right to take part in direction of their everyday lives and politics as a result of having performed the hardest work during the war. Listing the various intellectual categories of women, he pointed out that they had been working in their chosen fields before the war, in distinction to those women who were given the not easy and certainly not joyful opportunity by the war of working in an ironworks, operating machines and lathes, on the tramways, and in the depths of mines". There must be a change in women's situation and political rights, suffrage must be extended to those women who have demonstrated their worthiness by their steadfastness. We cannot "accept women's suffrage as the fruit of the political fights and sacrifices of working men and women in the place of the universal right to vote extended to men and women alike". Female suffrage would "bring the spirit of class battle into life among working women and the movement for suffrage would move into action again, and with great power, as a result of the stigmatization of working women as second-rate citizens" Kunfi concluded his speech, to the enthusiastic applause of his audience. ${ }^{7}$

6 Szociálpolitika és a nők választójoga, in: Nőmunkás, 1 August 1917, 5-6.

7 A munkásnők választójoga, in: Nőmunkás, 1 November 1917, 2-3. 


\section{Activity of the Association of Feminists in the suffrage movement}

The Association of Feminists was founded in Hungary on 18 December 1904 under the direction of Vilma Glüklich, a teacher from Budapest, with Dezső Márkus, a Justice of the Supreme Court, as vice-president of the association. This association was a significant actor of the movement for Hungarian women's rights from then on. ${ }^{8}$ Endeavours in the direction of political emancipation of women and the suffrage movement became the central aim of their activity, as Gábor Jánossy pointed out in his work entitled "Feminism in Hungary" (A feminizmus Magyarországon). In his opinion, "the principles, aspirations and truth of feminism are aims of the universal progress of humankind, the means of feminism are also those for the spread and generalization of civilization, its truths are based on the eternal principles of evolution, and their elemental power leads humankind towards a higher consummation, the prosperity of moral, physical and material improvement". The author emphasized in his work that feminism does not hinder political, social or economic development, and does not attack the institution of the family. On the contrary: it tries to support the education of women and children through its impact on social conditions. With their activities, feminists attempt to achieve a state of affairs in which women are no longer bound in their present subordinate role and limited sphere of activity, and they are no longer condemned to the role of a minor in the family either". 9

Gábor Jánossy also stressed that as women took up work and became independent breadwinners their position changed in society and in the family, the smallest community, as well. They had achieved a position equal to men. Alongside their responsibilities, women had become aware of their rights too, and they had now been given the opportunity to gain knowledge about the sciences, besides learning how to read and write. ${ }^{10}$

The Association of Feminists carried on its activities, including the suffrage movement, after the outbreak of the war. They covered almost all of their events in their journal „A Nö' (The woman) ${ }^{11}$ and they described how the war had changed women's situation. "We are experiencing the most significant changes in the everyday life and work of women," thus they reported on the new situation in the issue of their journal published on 5 April 1915. Men in the hinterland were not able to perform the work of those who were fighting in the front lines, and most of the work fell to the women's lot. "Now antifeminist men and women would be happy if we had more woman doctors, teachers and qualified clerks who could fill the gaps everywhere," pointed out the author of the article, Jolán Pflanczer. She called attention to the hard work of peasant women in her article. "Since they do

8 Andor MÁDAY, A magyar nő jogai a múltban és a jelenben, Budapest 1913, 135-136; Katalin SZEGVÁRI, A magyar feminista mozgalom a század elején, in: Valóság, 6, 1963, 4, 107-117; György LICSKÓ, A nők a közéletben. Összefoglaló a nemzetközi és a hazai szakirodalom alapján, in: A nő és a politikum. A nők politikai szerepvállalása Magyarországon, Mária PALASIK (ed.), Budapest 2007, 17-44.

9 Gábor JÁNOSSY, A feminizmus Magyarországon, Szombathely 1911, 15-16.

10 lbidem, 41-42.

11 A journal entitled ,A Nő és Társadalom' (Woman and society), the official newspaper of the National Associaton of Feminists and Female Clerks was published between 1907-1913. The journal was a forerunner of ,A Nö'. Its first editor was Róza Bédy Schwimmer. See LAKATOS, 2104. 
the housework, look after and rear their children, tend to the animals even in their tense, hamstrung state of mind, and besides all this they do all the outside work just as men did before, and meanwhile they are worrying about or mourning for their beloved ones. Considering all this work, a question inevitably arises: why is it that just these women are slighted and reckoned as not mature enough to exercise their civil rights."

It is, however, true that "the number of those working women who seriously want this is not big enough," stated the author. "But we should not be surprised if we think of the fact that many people even in the middle classes have been shuddering at the thought of having their daughters trained for any useful career". Still a lot of women would be able to make use of having a practical skill.

Many families spent all of their money and fortune on having their sons educated, hoping that as aged parents they would be able to rely on them and live in security in old age. The war despoiled them of their sure supporters. Almost every family was afflicted by the war; lots of women had to go to school to become able to make a living of their own. The result of the change in circumstances - as the author stated - was the independence of women and their success in the fields of their knowledge and individuality. Breadwinner women who supported their families and the widows and orphans realized by reason of their own experience "how much injustice and disregard is touches them without a proper representation of their interests".

Arising from their position they realize that "only they women themselves are able to protect their interests in a proper way as they have to fight for their rights themselves too". The author in the end of the article gave voice to her hope that after the war "women will have equal rights in all respects" and the realization of this will be pressed forward by public life..$^{12}$

In the Hungarian House of Representatives count Mihály Károlyi introduced a bill on 9 December 1915, in which he asked the representatives to vote in favour of suffrage for the heroes of the war, since they had demonstrated in the previous months their political reliability. ${ }^{13}$ Sándor Giesswien suggested that Károlyi's proposal should be modified (,A No"', 18 December 1915): "Considering that the broadest social layers and classes of the Hungarian people have given evidence of their patriotism, self-sacrifice and reliability in this war without distinction of gender, all uncertainty in the face of this bill should be dispelled. The House of Representatives orders the government to carry a bill in this term for the future realization of the right to vote on the basis of general suffrage and secret ballot, without any qualification of wealth or gender, and with a lowering of the iniquitous and unprecedented age limit."

The politician emphasized in the preamble to his amendment that the wartime country is following attentively and with compassion the heroic struggle of men and their sacrifices for the motherland, their separation from their families and their vanishing hopes. Not a bit less compassion is due to the mothers whose sons and husbands have been called away by the war, and to the girls who have lost their fathers or brothers. After the war - the representative continued - men and women would have to remedy the damage

12 A háború és a nő érvényesülése, in: A Nő, 5 April 1915, 57.

13 Képviselőházi Napló, 1910-1915. Vol. XXVII. Budapest 1916, 318-319. 
caused by the war together. Wages must be fixed equally, efforts must be made for an equal regulation of working hours; as hunger, an exhausted body, and injustice mean equal suffering for both men and women: it is hard to believe that not everyone understands and feels this even today". ${ }^{14}$

Szegvári Sándorné reported on a parliamentary debate on female suffrage in the issue of „A Nő' published on 5 January 1916. The author emphasized among other things that most of the parties of the opposition had asked for the extension of suffrage to a wider part of male population. In the preamble to their request it was stated that "these men have made so many sacrifices and suffered so much for our motherland during the war".

The leaders of the opposition parties are aware of the fact - she continued - that "women have suffered and made sacrifices in this war as well; that they have done much more: they have worked in the place of men, they have maintained the continuity of economic life". The leaders of the opposition parties "confront us with an insoluble riddle," she wrote. Mihály Károlyi, Vilmos Vázsonyi, István Rakovszky, Albert Apponyi „confess themselves as committed adherents of female suffrage [...] nevertheless they are worrying about the possibility that this issue would cause a discord in their collaboration".

"We have to bow to the mysteries of men's logic, and we have to listen through them giving spirited speeches [about people's rights] meaning by this that women are totally and by principal debarred from public affairs." Mihály Károlyi, for example stood up for peace, but he forgets that all of those who stood up for peace urged the granting of suffrage to women at the same time. The author mentioned Sándor Giesswein as a positive example, because he took a stand for female suffrage in any circumstances. Gyula Andrássy was mentioned as an example of the opponents who "do not consider the issue of suffrage as current regardless of whether it is for women or men".

The consequences of the war had illuminated social and economic deficiencies with an unprecedented sharpness. It became explicitly clear that greater and greater masses of women were forced into the position of bread-winner. Thus the leaders of the feminist movement endeavoured to call the attention of women to the necessity for education more and more widely. "And suffrage means bread, just as it does for men, for those women who cannot or do not want to be dependent on a man," stated Sándorné Szegvári. ${ }^{15}$

The leadership of the Association of Feminists sent a questionnaire to representatives in April 1917 which contained four questions. The aim of the leaders of the movement was to find out whether the representatives' opinion had changed and, if yes, to what degree in the question of female suffrage.

"1. Are you willing to submit a motion in parliament regarding women's suffrage? 2. Can we reckon on your vote in favour of such a motion if someone else submitted the motion? 3. Are you an adherent of the universal suffrage of women? 4. If you are an adherent of women's suffrage based on qualifications, how much would you change it and for what reasons?"

The external appearance of those surviving documents which were returned and which are in the Feminist Collection of the Hungarian State Archive is informative. Many of the

14 Dr. Giesswein Sándor a nők választójogáért, in: A Nő, 12. szám (number), 18 December 1915. (A speech of Sándor Giesswein. See: Képviselőházi Napló 1910-1915. Vol. XXVII., Budapest 1916, 361-362.)

15 Háború és választójog, in: A Nő, 5. January 1916, 2-3. 
representatives frankly revealed their opinion and signed the questionnaires. Some gave a one-word answer, while others gave the grounds for their answers in detail. Mátyás Skrovina, a lawyer and the representative of the constituency of Zólyom joined the four questions with a bracket and wrote only one word: "No!”.

In connection with the information provided by the content of the surveys we can state as follows: 66 of the answers of the Representatives were sent back according to the summary. The representatives wrote either their own or their party's opinion. Those who interpreted the opinion of their party did this with extra stress on it. Here we introduce some of the opinions of the representatives which show how important the issue of female suffrage was for them and how seriously they took it. There were some representatives who could not answer the questions because their party had not yet defined its attitude.

Count Gyula Andrássy „will demand the suffrage of women if and when a reform of suffrage that exceeds the suffrage of the heroes is placed on the agenda".

Count Albert Apponyi "does not make a party issue of this question. He himself is an adherent of qualifications".

János Baross, an independent representative, replied only to the fourth question. In his opinion "suffrage should be provided for all the wives of the male voters," if they can read and write. He pondered the question of granting suffrage to mothers of many children as well.

János Benedek, a liberal representative, a member of the opposition, replied as follows to the first question: "In this parliament - no: I do not want to waste my breath". Regarding the second and third questions he gave a positive answer and supported every submission in this issue. He was an adherent of total equality before the law. He suggested qualifications only in such a case that universal suffrage could not be achieved at the first attempt. In that case he would have provided suffrage for every woman who had an independent income, who was a supporter of her family, and who had some level of education.

Sándor Giesswein, a representative of the Christian Socialist Party, expressed in his reply to the first and second questions that he supported every submission that takes a stand on women's suffrage, as he had done in the past as well. He declared in addition that he was an adherent of universal suffrage and he demanded suffrage for women as well. Supposing it was not possible to achieve universal suffrage he demanded equality between women and men in relation to suffrage.

Károly Huszár, president of the Christian National Union, in his reply to the first question expressed that he was not willing to submit a proposal in the case of women's suffrage but he would support a proposal by somebody else. He did not support the universal suffrage of women. He evolved his opinion supporting a suffrage based on qualifications. He would grant suffrage to those women who had a degree, who had completed a ladies' college or the fourth class of a girl's school and who were independent breadwinners.

Béla Kelemen, a Representative of the Kossuth Party, replied with a decisive "No" to each of the first three questions. His opinion as expressed in the reply to the fourth question was as follows: "I do not refuse in principle granting women political rights and the possibility of influencing the public affairs of the country. My opinion is that those women may be empowered by the right to actively take part in political life and the fights of political parties without threatening to destroy their femininity or their suitability to fulfil the noble 
mission of life who are of full age, have completed higher elementary school, and have an independent income."

Count György Pallavicini, independent representative at that time, answered only the third question concerning the merits of the issue. He thought that universal suffrage for men should be guaranteed first. He deemed women's suffrage untimely, though he was not against it in principle, and he was sure that "it has to be created soon".

Vilmos Sümegi, the leader of the Independence and 1848 Party, would not have submitted an independent proposal in parliament, but he would have voted for and supported a proposal concerning suffrage for all women.

György Szmercsányi, a representative of the Liberal (Szabadelvü - literally ,freethinker') Party, would either have submitted and/or supported any proposal regarding female suffrage. But he would have granted suffrage only to those women who "work in intellectual professions and maintain themselves and their families".

Gábor Ugron, a representative of the Constitution Party, did not answer the first three questions. He would have based suffrage on an educational qualification - four grades of higher elementary school or a higher level of education. If an educational level qualification were not feasible, he would have proposed a property qualification, namely extending the vote to those women who were liable for a government tax of 20 crowns or more.

Sándor Wekerle, a representative and former three-time prime minister, did not reply to the first three questions. He would have supported a proposal for women's suffrage submitted by others. He too would have based it on an educational qualification. ${ }^{16}$

The Association of Feminists convened a national conference for women's suffrage on 11 September 1917, as reported in "A Nö' on 15 September. The objective of the national conference was to make it clear to everyone that participation in conducting public affairs was not the privilege of a small group of women or urban women but of every citizen who had attained their majority. The participants in the conference wanted to convince society that women with different qualifications are aware of the tasks awaiting them in politics. The speakers of the conference from the most various social strata elaborated their points of view in favour of the realization of the extension of rights.

Oszkárné Szirmai, the president of the Association of Feminists in Nagyvárad, stood for the standpoint of the housewives. She submitted a declaratory resolution to the conference in which she argued out the importance of a governmental reform of suffrage and she gave voice to her hope that "the proposal will extend universal civil rights to all of those women who can assert a right to it on the basis of fulfilling the serious duties of life". (Her proposal was accepted with general enthusiasm by the participants in the conference.)

Imréné Turcsányi, the president of the Association of Feminists from Szeged, spoke about the rights of mothers. She listed those urgent measures that would provide a better situation for women in their families and in the upbringing of their children.

Istvánné Bordás, the president of the association of peasant women from Balmazújváros "depicted the situation of working women in agriculture with alarming words: starvation wages, unbearably high prices, the suffering caused by the war, the unjust and cold cruelty of governmental administration". She considered the extension of suffrage to be the only

16 Magyar Nemzeti Levéltár (Hungarian National Archive in Budapest). P 999. fond 14. doboz (box) 37, tétel (item), 49-56. 
possible way of solving the huge problem. In possession of it - in her opinion - women will be able to change war "as they would have been able to prevent the present one if they had obtained their civil rights in time" she said.

Janka Gergely, the president of the Women Clerks Association, listed statistical data in support of the fact that the laws of that time served the interests of those classes whose representatives were in parliament and had neglected the interests of women up to that time.

Dr. Valéria Dienes, gave a speech about the suffrage of graduate women and joined the declaratory resolution submitted by Oszkárné Szirmai. She called attention to the injustice of the qualifications on female suffrage.

Minister Vilmos Vázsonyi saw the delegates from the country of the national conference and assured them that "true benevolence will be combined with great creative power during the process of framing the bill". He said, moreover, that during the preparation of the bill he would use foreign examples in favour of success. ${ }^{17}$

\section{The bill of Vilmos Vázsonyi}

Vilmos Vázsonyi, minister of suffrage without portfolio, laid his bill before the House of Representatives. He would have grant the right to those men over the age of 24 who had completed the fourth grade of elementary school, or paid tax amounting to at least 10 crowns, or had served as a soldier for at least two years and reached the position of warrant officer, or had received either a medal for bravery or the so-called Károly-troop Cross, or who was an independent craftsman, tradesman, or who was employed as an agricultural worker, industrial worker or farm-servant. Vázsonyi would have granted suffrage to all the women of Hungarian nationality over the age of 24 who could write and read, had completed the fourth grade of higher elementary school or who were a war-widow with a child/children, or who were members of a cultural or scientific society that had been active for at least two years. He was the first member of the government who wanted to grant the right to vote to women in a bill - even if on the basis of some kind of qualification. ${ }^{18}$

Vázsonyi called a suffrage committee of 48 members into being on 17 January 1918 to discuss the suffrage bill that had been submitted by the government on 21 December 1917. The committee discussed the bill between 8 February and 7 June 1918 over the course of 31 sessions. ${ }^{19}$

The bill aroused a debate among the members of the suffrage committee too. The operative word concerning the bill was declared by the committee: 34 of the 48 members supported and 14 were against women's suffrage. István Tisza put the bill to the vote in the suffrage committee when the majority, 11 of the opponents' 14 members were present, thus the suffrage committee did not support the bill. ${ }^{20}$ After the unfavourable decision the debate of the House continued for three more weeks, from 25 June to 19 July 1918. ${ }^{21}$

17 Az ország asszonyai a választójogért, in: A Nő, 15 September 1917, 139.

18 Alajos KOVÁCS, A magyar választójogi reformok számszerū hatása, Budapest 1925, 11.

19 Országgyűlés Nyomtatványai , LXII. 1450. szám, Budapest, 1918. 1.

20 Miért szavazták le a nők választójogát a bizottságban?, in: A Nő, 91, szám (number), June-July 1918.

21 Képviselőházi Napló, Vol. XL., Budapest 1918, 447-448. 
Sándor Wekerle, the prime minister, declared himself an adherent of women's suffrage in the speech he gave on 11 July. He brought the fact forward as an argument, among others, that due to the changes that had taken place in society, women had participated in various types of work besides housework, and a great many of them had got into public service. However, as far as female suffrage was concerned, his opinion was "do not go proceed so far - I myself would not do so either - as many Western-European countries, which have granted (or at least would like to grant) the same rights to women as to men" [...] I would not go far, because this issue is not only about extending rights, but also about their consequences on society in connection with that, and I would warn everybody against rapid innovations in society; but we have to go to the limit where women can be decisive factors in public life, and we have to grant them suffrage within this limit," as the prime minister added in support. ${ }^{22}$

The unfavourable opinion of the suffrage committee made it explicit to the prime minister that saving women's suffrage would be possible only if it was discussed in parliament as an independently proposed amendment to the universal suffrage bill. Thus he presented a proposal on 12 July 1918 in which he named three possible sets of terms for the regulation of women's suffrage in favour of its realization.

From the first proposal of Vázsonyi there was the condition of four completed grades of higher elementary school or some other qualification equal to this. According to the second proviso, suffrage could have been granted to those women who were the wives or widows of men with a qualification from the highest grade of high school, or a higher elementary school, or a military educational institution equal to it. According to the third, those unmarried or divorced women would have been granted suffrage who worked in agriculture, industry or commerce and paid a direct government tax amounting at least to 100 crowns (either from one or several tax categories at the same time) in one or more communities. ${ }^{23}$ The proposal of the prime minister again gave rise to a serious debate.

Vilmos Vázsonyi for example gave 13 speeches during the debate on the articles of the bill in the parliament in favour of women's suffrage. One of the most important was delivered on 17 July 1918. In the first part of his speech he responded to the objections which had been raised against women's suffrage on the basis of often declared arguments.

In Vázsonyi's opinion many stuck to their prejudices and did not give proper reasons why they wanted to exclude women from suffrage, since "those worn-out arguments of the tranquillity of family life from where women must not be invited to participate on political sphere are obsolete little arguments, not real reasons".

The deputies arguing about the bill did not recognise the essential logical contradictions between women's position under civil law and their capacity to act in public law. In civil law women could participate in economic life, they had the right of disposal over their own property, they could enter into contracts, practise their private rights equally to men, while they were thought to be unsuitable to practise public law. „[...] in public law we maintain henceforth the partitions of public law's harem, and we do not want to let women practise public law". ${ }^{24}$

22 lbidem.

23 lbidem, 490-491.

24 Vázsonyi Vilmos beszédei és írásai. Vol. II., Budapest 1927, 228-229. 
The vote on the subject of women's suffrage took place on 17 July 1918. Altogether 11 proposals were to be resolved. It is worth mentioning that Gyula Andrássy proposed before the voting started that female suffrage should have been regulated by the House of Representatives separately from the bill. The legal title of completing the four grades of higher elementary school was rejected in the ratio by 161 to 96 . Suffrage based on the husband's right to vote got so few votes that they were even not counted.

With this the fate of women's suffrage was sealed and its support in the Upper House was not worth mentioning. ${ }^{25}$ Eventually the XVVII th Act of 1918 arose from the bill framed by the Wekerle government with little modification and was passed in the House of Representatives on 19 July 1918. (Thus this act actually was not the suffrage of Vázsonyi as is often mentioned - even today - and in fact Vázsonyi himself often protested against this, with reason, since it was based on different premises.)

The XVII th Act of 1918 laid down several universal and specific conditions the right to vote. In the case of men the universal conditions were as follows: that they be 24 years of age, have Hungarian citizenship, be literate, have been living for at least one year at the same settlement. The special conditions were: the completion of 6 grades of elementary school, the payment of 10 crowns tax, hold property of 8 acres of plough-land, or be an independent craftsman or tradesman, be in permanent employment, be a warrant officer, have been awarded a gold or silver medal for bravery, be a member of a voter's family supporting it, or a holder of the Karoly-cross. Those who had been awarded a bravery medal and / or the Karoly-cross had the right to vote even if they were under the age of 24. Nevertheless women's suffrage was totally left out. ${ }^{26}$

While the fate of the Austrian-Hungarian Monarchy was already sealed before the end of the war, it was only fulfilled in the autumn of 1918. When the armistice agreement was signed on 3 November 1918 in Padova, in reality neither the Monarchy nor the dualistic system existed any longer.

The Hungarian National Council was founded on 24 October 1918 under the direction of Mihály Károlyi. The Council took a stand on the question of the formation of a national democratic government in their proclamation and demanded the prompt ending of the war, new elections on the basis of universal and secret voting, agrarian and welfare reforms and freedom of assembly and association. The National Council represented the politics of the liberal middle-classes that were supported by the social democrats too. ${ }^{27}$

The bourgeois-democratic revolution gained its victory on 31 October 1918. In the programme of Károlyi's government suffrage reform was included. The first ,People's Law' of 1918 granted the right to vote to every man who was over the age of 21 and had had Hungarian citizenship for at least 6 years. The act specified the following as the conditions for women's suffrage: that she be over the age of 24, have 6 years Hungarian citizenship and be literate. ${ }^{28}$

25 Katalin NAGYNÉ SZEGVÁRI, A női választójog külföldön és hazánkban, Budapest 2001, 122.

26 KOVÁCS, 12; Magyar Törvénytár, Budapest 1919, 124-131.

27 Magyarország a XX. században, Sándor BALOGH (ed.), Budapest 1986, 69.

28 KOVÁCS, 13-14. 
The victory of the bourgeois revolution and the "People's Law' resulted in huge changes in politics, the extension of rights changed the general way of thinking of the people and created new opportunities for workers such as had not existed before. The relations of power between the political parties changed as well, besides the existing parties the possibility of creating an important force became accessible for the Social Democratic party. A greater part of the crowds of workers who were given the right of voting saw the realization of the representation of their interests in the Social Democratic party and joined it.

The suffrage bill of the People's Law - which brought about a great political impulse - was framed in March 1919. The date of voting was set for the 14 April 1919 (the anniversary of the dethronement of the Habsburgs in 1849) and it was a realization of the establishment of Hungarian Soviet (Council) Republic.

\section{Abstract}

After the outbreak of "Big War" the role of the wartime hinterland has changed essentially. Some of the political parties and social organizations considered that men doing their military service in the war would have deserved the extension of suffrage and women in the wartime country would have deserved to gain suffrage. One of those political parties which had the biggest mass support performed political activity for the extension of suffrage. As the Social Democratic Party gained ground its increasing popularity brought about the establishment of the organization framework of the social democratic women's rights movement, and this then reinforced its activity, launching a journal called ,Nőmunkás' (The Woman Worker). The journal described the struggle, everyday problems, means of subsistence faced by women and the parliamentary debates concerning female suffrage that did not yield a result until December of 1917.

One of the most significant of the social organizations was the Association of Feminists which was founded in Hungary on 18 December 1904. Endeavours in the direction of political emancipation of women and the suffrage movement became the central aim of their activity. The journal of the Association titled "A No"" (The Women) covered almost all of their programmes, described how the situation and position of women changed due to the war and called attention to the debates concerning suffrage and published the various views of politicians and political parties. The first significant breakthrough in these debates was a bill that was brought in the parliament by Vilmos Vázsonyi, a minister without portfolio on 21 December 1917. He was the first member of a government who was willing to provide suffrage for women even though based on qualifications. His bill aroused an important dispute among common people and politicians too. Despite of all his efforts and political arguments the bill he proposed was not supported thus the law that was passed in the parliament did not included female suffrage.

\section{Keywords}

World War I, extension of suffrage in the wartime, the political parties for extension of suffrage, parliamentary debates of suffrage in 1917 


\section{References}

Magyar Nemzeti LevéltárHungarian National Archive in Budapest

Fond P 999, 14

Politikatörténeti és Szakszervezeti Levéltár

Archive of History of Politics and Trade Unions in Budapest

Fond 940, 14

A Nő, 5 April 1915

A Nő, 18 December 1915.

A Nő, 5. January 1916

A Nő, 15 September 1917

A Nő, 91, szám (number), June-July 1918.

Nőmunkás, 15 February 1915

Nőmunkás, 15 December 1915

Nőmunkás, 1 August 1917

Nőmunkás, 1 November 1917

BALOGH, Sándor (ed.): Magyarország a XX. században, Budapest 1986.

JÁNOSSY, Gábor: A feminizmus Magyarországon, Szombathely 1911.

Képviselőházi Napló, 1910-1915, Vol. XXVII, Budapest 1916.

Képviselőházi Napló, 1910-1915, Vol. XL, Budapest 1918.

KOVÁCS, Alajos: A magyar választójogi reformok számszerű hatása, Budapest 1925.

LAKATOS, Éva: Magyar Irodalmi Folyóiratok. A Petőfi Irodalmi Múzeum Bibliográfiai Füzetei, Budapest. 1981, A, sorozat (series) 17-19.

LICSKÓ, György: A nők a közéletben. Összefoglaló a nemzetközi és a hazai szakirodalom alapján, in: A nő és a politikum. A nők politikai szerepvállalása Magyarországon, Mária PALASIK (ed.), Budapest 2007, 17-44.

MÁDAY, Andor: A magyar nő jogai a múltban és a jelenben, Budapest 1913.

Magyar Törvénytár, Budapest 1919.

NAGYNÉ SZEGVÁRI, Katalin: A női választójog külföldön és hazánkban, Budapest 2001.

SIMÁNDI, Irén: Küzdelem a nők parlamenti választójogáért Magyarországon 1848-1938, Budapest 2009.

SZEGVÁRI, Katalin: A magyar feminista mozgalom a század elején, in: Valóság, 6, 1963, 4, 107-117.

Vázsonyi Vilmos beszédei és írásai. Vol. II., Budapest 1927. 